\title{
Assessment of Serum Magnesium Concentration in Patients with Knee Osteoarthritis
}

Amira Abdel-Aziz*, Amir Abdel-Rahman, Amany Salama, Mohammed Hossam Eldeen Zaghloul

Department of Rheumatology and Rehabilitation, Faculty of Medicine, Mansoura University, Egypt.

*Corresponding author: Amira Abdel-Aziz, Mobile: (+20) 01221490420, E-Mail: ameraabdelaziz1989@gmail.com

\begin{abstract}
Background: Magnesium, which is an essential trace element in bone metabolism, has been paid to great attention in recent years due to its osteogenic effect and critical role in bone mineralization process.

Objective: Detection of the association between serum $\mathrm{Mg}$ concentration and clinical and radio-graphical findings in patients with knee OA and in apparently healthy controls.

Subjects and method: A cross-sectional study conducted on 100 female patients with primary knee osteoarthritis (OA) diagnosed according to the American College of Rheumatology (ACR) clinical and radiological classification criteria for knee OA. In addition, 100 apparently healthy volunteers with no features of OA matched for age and sex worked as control group. All the study populations underwent bilateral weight bearing anteroposterior x-ray of the knee which was assessed according to the Kellgren and Lawrence (KL) grading system. The Western Ontario and McMaster Universities Arthritis Index (WOMAC) and Visual Analogue Scale (VAS) were used to assess pain severity and functional limitation. Blood samples had been collected for assessing serum $\mathrm{Mg}$ concentration by colorimetric method.
\end{abstract}

Results: The mean serum $\mathrm{Mg}$ level in the OA group was $1.97 \pm 0.17 \mathrm{mg} / \mathrm{dl}$ and the mean level of $\mathrm{Mg}$ in the control group was $2.09 \pm 0.15 \mathrm{mg} / \mathrm{dl}$ with high statistically significant difference between the two groups $(\mathrm{p}<0.001)$.

Conclusion: Serum Mg concentration may have an inverse relationship with radiographic knee OA. Therefore, high level of Mg could possibly exert a protective role in the control of knee OA and can be used in its management.

Keywords: Knee osteoarthritis, KOA, Magnesium, Mg, forgotten mineral.

\section{INTRODUCTION}

Osteoarthritis is a type of degenerative disorder of the joints characterized by a combination of degenerative, inflammatory and reparative process that can result in defect in articular cartilage, change in subchondral bone and synovial inflammation ${ }^{(\mathbf{1})}$.

In the ACR Clinical/Radiographic classification criteria, the presence of knee pain with at least one of the following three items along with osteophyte in knee X-ray can classify the knee OA: Age $>50$ years old, morning stiffness $<30$ minutes, crepitus on knee motion ${ }^{(2)}$. With further increase in prevalence of knee OA, there is an increasing rate of knee arthroplasty performed, which is currently the only effective treatment for the late phase of OA. Diagnosis of early osteoarthritis can significantly improve the quality of life, save cost and decrease incidence of disability and morbidity related to OA. These facts have made identification of effective conservative and preventive measures for knee OA a high priority ${ }^{(3)}$.

Magnesium $(\mathrm{Mg})$ as an essential trace element in bone metabolism has been paid to great attention in recent years according to its osteogenic effect and critical role in bone mineralization process ${ }^{(4)}$. Serum magnesium measurement is the most available and commonly employed test to assess magnesium state ${ }^{(5)}$. The normal serum magnesium concentration is 0.75 to $0.95 \mathrm{mmol} / \mathrm{L}$, and a level of less than $0.75 \mathrm{mmol} / \mathrm{L}$ is considered $\mathrm{Mg}$ depletion ${ }^{\left({ }^{6}\right)}$. There are several mechanisms by which low magnesium intake may contribute to OA pain, including proinflammatory effects of magnesium deficiency, and its role in pain sensitization ${ }^{(7)}$. Low magnesium has been associated with elevated serum levels of C-reactive protein ${ }^{\left({ }^{(8)}\right.}$. Mg also decreases the prevalence of metabolic syndrome and DM, which were reported to be risk factors for OA progression ${ }^{(9)}$.

Finally, despite its importance, $\mathrm{Mg}$ is referred to by some as the "orphan" or "forgotten" cation. Increasing the awareness on $\mathrm{Mg}$ may focus greater clinical attention to its important role in health and disease ${ }^{(5)}$. The aim of this study was to find out the association between serum $\mathrm{Mg}$ concentration and clinical and radiographical findings in patients with knee OA and in apparently healthy controls.

\section{PATIENTS AND METHOD}

This is a cross-sectional study, which was done on 100 female patients with primary knee osteoarthritis and 100 controls age and sex matched. Patients were selected from the Department of Rheumatology and Rehabilitation in Mansoura University Hospital (from January 2018 - January 2019). They were diagnosed according to American College of Rheumatology clinical and radiological classification criteria for knee OA.

Inclusion Criteria: 50 years old or above, female gender, normal renal function, and bilateral weight bearing anteroposterior radiography of the knee.

Exclusion Criteria: Younger than 50 years old, male gender, and radiographic evidence of non-osteoarthritis joint disease (e.g., chondromalacia patella and rheumatoid arthritis), and renal abnormalities. 
The scoring systems that we used to assess pain and function were:

Visual Analogue Scale: It's a $(0-10)$ scale used to assess the severity of knee pain. Pain intensity ranges from 0 (no pain) to 10 (the worst pain).

\section{Western Ontario and McMaster Universities Arthritis Index: \\ It's a questionnaire formed of 3 parts and each part} assesses different item including pain, stiffness and functional limitation in the activities of daily living (ADL). The total score is 96 (96 is the worst).

Kellgren and Lawrence score ${ }^{(10)}$ : It's used to assess the weight bearing anteroposterior $\mathrm{x}$-ray of the knee graded from (0-4).

In our study, patient's knee joint should be graded K-L 2 or above at least in one knee joint. If the patient has different K-L grade in bilateral knees, we select the severest one for data analysis.

Serum sample was used to assess the $\mathrm{Mg}$ concentration and the test was done chemically by colorimetric method using xylidyl blue reagent. It is based on the reaction of $\mathrm{Mg}$ with xylidyl blue reagent at alkaline $\mathrm{pH}$, which yields a purple colored complex. The intensity of the color is proportional to the $\mathrm{Mg}$ concentration.

\section{Sample preparation:}

After collection of the whole blood, $2 \mathrm{ml}$ were allowed to clot in room temperature 15-30 minutes then centrifuge for 20 minutes to get the serum sample. The serum was mixed well with the reagent for 10 minutes at room temperature, and then we read the absorbance of the sample and slandered against reagent blank. The color is stable for at least 1 hour. NB: Serum with any visible hemolysis can't be used because of the large amount of $\mathrm{Mg}$ released from the erythrocytes. Expected values: Female serum Mg concentration $=1.9-2.5 \mathrm{mg} / \mathrm{dl}$ (0.77-1.03 mmol/l).

\section{Ethical consideration:}

A signed informed written consent was obtained from every patient before the procedures. The study was conducted after the approval of Institutional Research Broad (IRP) of the Faculty of Medicine, Mansoura University, Egypt.This work has been carried out in accordance with The Code of Ethics of the World Medical Association (Declaration of Helsinki) for studies involving humans.

\section{Statistical analysis}

All statistical analysis were performed using Microsoft excel and statistical package for social science (SPSS) software. Parametric data (continuous) were expressed as mean \pm standard deviation (SD). The difference between groups or more were determined using one way analysis of variance (ANOVA) test. The Spearman Rank test was used to determine the correlation between two variables containing non parametric data (non-continuous). Statistical significance was set as $\mathrm{p} \leq 0.05$.

\section{RESULTS}

According to the assessment of pain at rest by visual analogue scale, 44 cases $(44 \%)$ had score 0,32 cases $(32 \%)$ had score 2,17 cases $(17 \%)$ had score 3,4 cases (4\%) had score 4 and 3 cases (3\%) had score 5 (Figure 1).

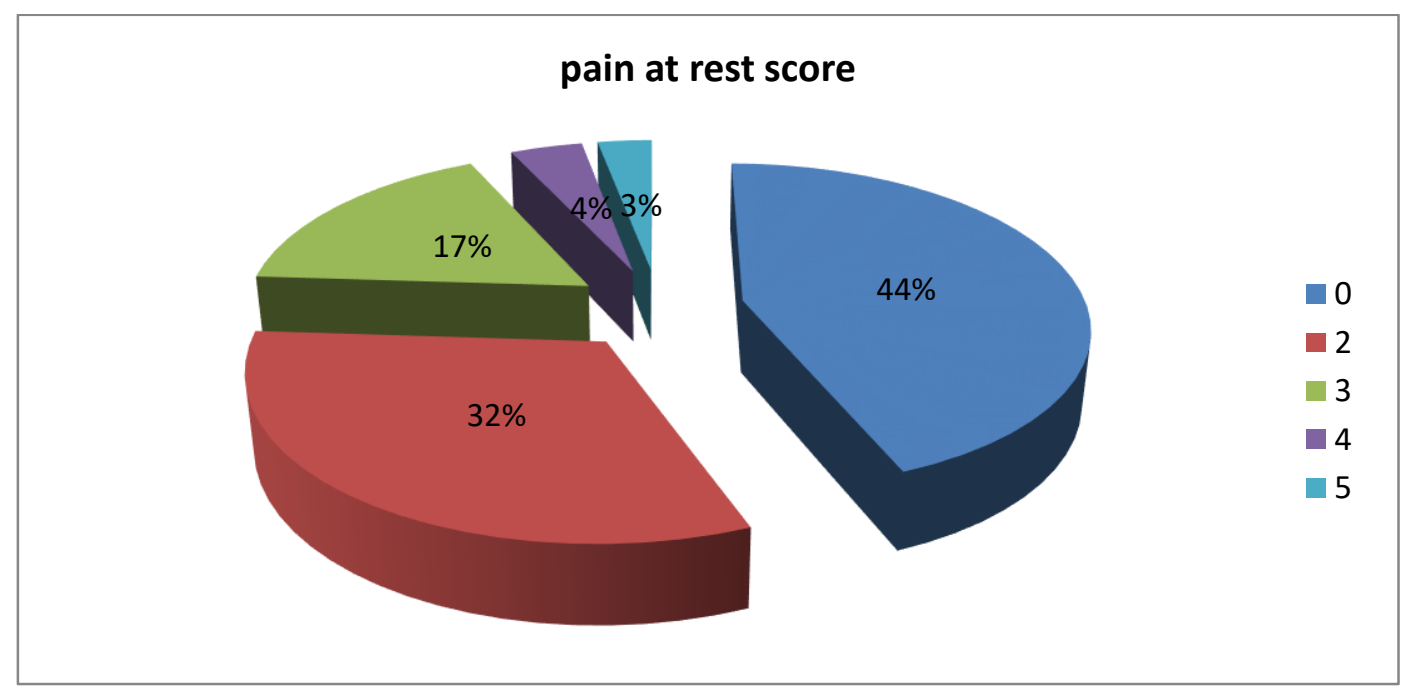

Figure (1): Pain at rest by visual analogue scale.

According to the assessment of pain at daily living activity by visual analogue scale, 1 case (1\%) had score 3,2 cases $(2 \%)$ had score 4,31 cases $(31 \%)$ had score 5,10 cases $(10 \%)$ had score 6,40 cases $(40 \%)$ had score 7,11 cases (11\%) had score 8 and 5 cases (5\%) had score 10 (figure 2). 


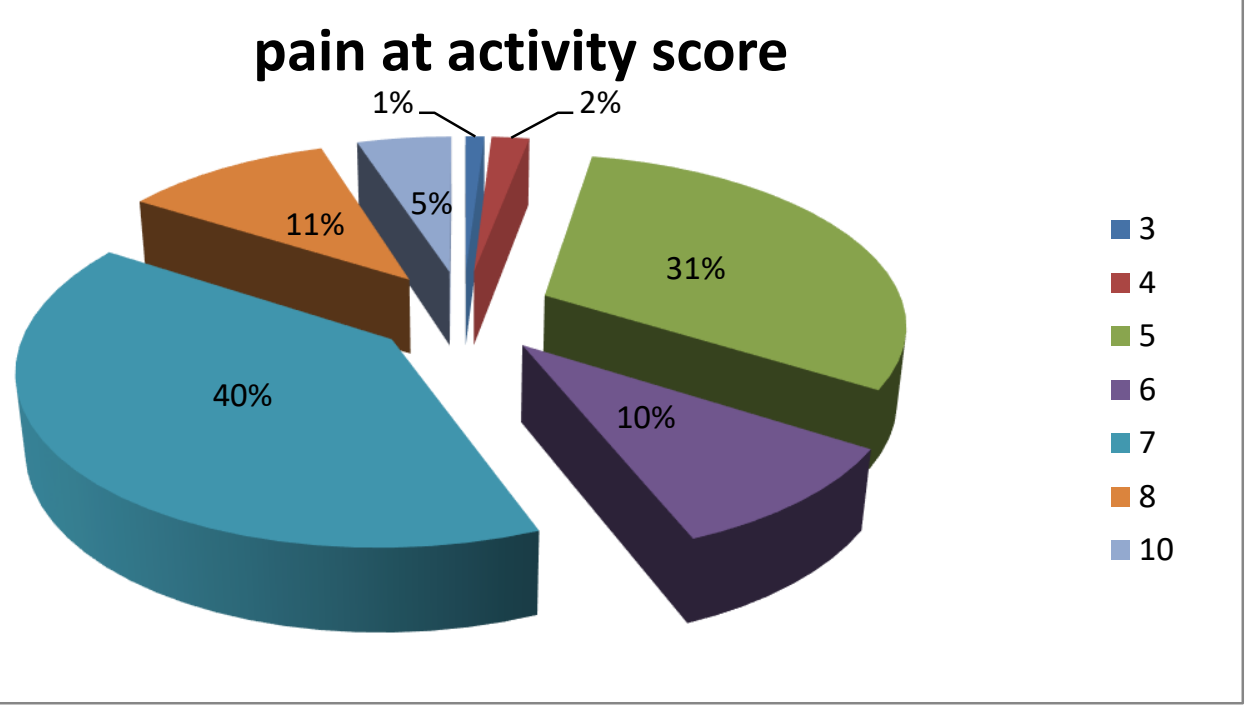

Figure (2): Pain at activity by visual analogue scale. 4 (figure 3).

Regarding the KL score, 40 cases (40\%) had score 2, 42 cases (42\%) had score 3 and 18 cases (18\%) had score

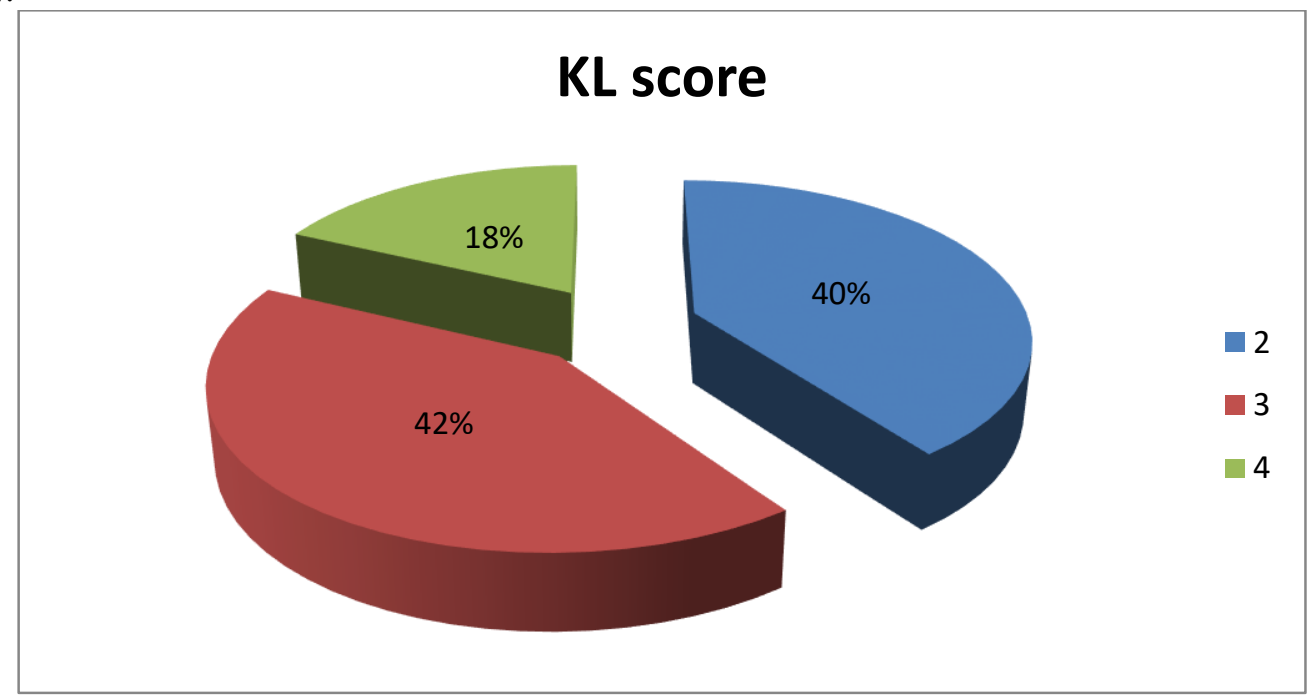

Figure (3): Case distribution according to KL score.

The mean serum $\mathrm{Mg}$ level in the OA group was $1.97 \pm 0.17 \mathrm{mg} / \mathrm{dl}$ and the mean level of $\mathrm{Mg}$ in the control group was $2.09 \pm 0.15 \mathrm{mg} / \mathrm{dl}$ with high statistically significant difference between the two groups $(\mathrm{p}<0.001)$.

Table (1): Comparison of serum Mg levels in the OA patients and the control group

\begin{tabular}{|c|c|c|c|}
\hline & $\begin{array}{c}\text { Knee OA } \\
\text { group } \\
\mathbf{N}=\mathbf{1 0 0}\end{array}$ & $\begin{array}{c}\text { Control } \\
\text { group } \\
\mathbf{N}=\mathbf{1 0 0}\end{array}$ & $\begin{array}{c}\text { Test of } \\
\text { significance }\end{array}$ \\
\hline $\begin{array}{c}\text { Mean } \mathrm{Mg} \\
\text { level } \\
(\mathrm{mg} / \mathrm{dl})\end{array}$ & $1.97 \pm 0.17$ & $\begin{array}{c}2.09 \pm \\
0.15\end{array}$ & $\begin{array}{c}\mathrm{t}=-5.709 \\
\mathrm{P}< \\
0.001^{*}\end{array}$ \\
\hline
\end{tabular}

P: probability. Continuous data expressed as mean \pm SD. $\mathrm{T}=$ independent samples $\mathrm{t}$-test.

*: statistically significant $(\mathrm{p}<0.05)$

The mean serum $\mathrm{Mg}$ level in the normal CRP group was $1.97 \pm 0.16 \mathrm{mg} / \mathrm{dl}$ and the mean level of Mg in the high CRP group is $1.95 \pm 0.14 \mathrm{mg} / \mathrm{dl}$ with no statistically significant difference between the two groups $(\mathrm{p}=0.452)$. Furthermore, the mean serum $\mathrm{Mg}$ level in the normal ESR group was $1.98 \pm 0.14 \mathrm{mg} / \mathrm{dl}$ and the mean level of $\mathrm{Mg}$ in the high ESR group was $1.95 \pm 0.18 \mathrm{mg} / \mathrm{dl}$ with no statistically significant difference between the two groups $(\mathrm{p}=0.454)$ as shown in table (2).

Table (2): Comparison of serum $\mathrm{Mg}$ levels according to CRP, ESR levels

\begin{tabular}{|c|c|c|c|}
\hline & $\begin{array}{c}\text { Normal } \\
\text { CRP } \\
N=64\end{array}$ & $\begin{array}{c}\text { High CRP } \\
N=36\end{array}$ & $\begin{array}{c}\text { Test of } \\
\text { significance }\end{array}$ \\
\hline \multirow{3}{*}{$\begin{array}{c}\text { Mean Mg } \\
\text { level } \\
(\mathrm{mg} / \mathrm{dl})\end{array}$} & $1.97 \pm 0.16$ & $\begin{array}{c}1.95 \pm \\
0.14\end{array}$ & $\begin{array}{c}\mathrm{t}=0.756 \\
\mathrm{P}=0.452\end{array}$ \\
\hline & $\begin{array}{c}\text { ESR } \\
\text { within the } \\
\text { reference } \\
\text { range } \\
N=56\end{array}$ & $\begin{array}{c}\text { High ESR } \\
N=44\end{array}$ & $\begin{array}{c}\text { Test of } \\
\text { significance }\end{array}$ \\
\hline & $1.98 \pm 0.14$ & $\begin{array}{c}1.95 \pm \\
0.18\end{array}$ & $\begin{array}{c}\mathrm{t}=0.767 \\
\mathrm{P}=0.454\end{array}$ \\
\hline
\end{tabular}

The mean serum $\mathrm{Mg}$ level in the diabetic group was $1.98 \pm 0.16 \mathrm{mg} / \mathrm{dl}$ and the mean level of $\mathrm{Mg}$ in the 
non-diabetic group was $1.96 \pm 0.14 \mathrm{mg} / \mathrm{dl}$ with no statistically significant difference between the two groups $(\mathrm{p}=0.685)$. The mean serum $\mathrm{Mg}$ level in the group of cases with dyslipidemia was $1.98 \pm 0.15 \mathrm{mg} / \mathrm{dl}$ and the mean level of $\mathrm{Mg}$ in the group without dyslipidemia was $1.94 \pm 0.16 \mathrm{mg} / \mathrm{dl}$ with no statistically significant difference between the two groups ( $\mathrm{p}=0.191)$. The mean serum $\mathrm{Mg}$ level in the non-hypertensive group was $1.97 \pm 0.17 \mathrm{mg} / \mathrm{dl}$ and the mean level of $\mathrm{Mg}$ in the hypertensive group was $1.96 \pm$ $0.14 \mathrm{mg} / \mathrm{dl}$ with no statistically significant difference between the two groups $(\mathrm{p}=0.880)$ (Table 3$)$.

Table (3): Comparison of serum $\mathrm{Mg}$ levels in diabetic, non-diabetic, dyslipidemic, non-dyslipidemic, hypertensive and non-dyslipidemic groups

\begin{tabular}{|c|c|c|c|}
\hline & $\begin{array}{c}\text { Diabetic } \\
\text { (type 2) } \\
N=26 \\
\end{array}$ & $\begin{array}{c}\text { Non } \\
\text { diabetic } \\
N=74 \\
\end{array}$ & $\begin{array}{c}\text { Test of } \\
\text { significance }\end{array}$ \\
\hline \multirow{5}{*}{$\begin{array}{c}\text { Mean Mg } \\
\text { level } \\
(\mathrm{mg} / \mathrm{dl})\end{array}$} & $1.98 \pm 0.16$ & $1.96 \pm 0.14$ & $\begin{array}{c}\mathrm{t}=0.407 \\
\mathrm{P}=0.685\end{array}$ \\
\hline & $\begin{array}{c}\text { Dyslipidemic } \\
N=62\end{array}$ & \begin{tabular}{|c|} 
Non \\
Dyslipidemic \\
$N=38$
\end{tabular} & $\begin{array}{c}\text { Test of } \\
\text { significance }\end{array}$ \\
\hline & $1.98 \pm 0.15$ & $1.94 \pm 0.16$ & $\begin{array}{c}\mathrm{t}=1.316 \\
\mathrm{P}=0.191\end{array}$ \\
\hline & $\begin{array}{c}\text { Non } \\
\text { hypertensive } \\
N=68\end{array}$ & $\begin{array}{c}\text { Hypertensive } \\
N=32\end{array}$ & $\begin{array}{c}\text { Test of } \\
\text { significance }\end{array}$ \\
\hline & $1.97 \pm 0.17$ & $1.96 \pm 0.14$ & $\begin{array}{c}\mathrm{t}=0.151 \\
\mathrm{P}=0.880\end{array}$ \\
\hline
\end{tabular}

\section{DISCUSSION}

This was a cross-sectional study identifying an inverse correlation between serum $\mathrm{Mg}$ concentration and severity of OA of the knee. The primary focus on the connection of $\mathrm{Mg}$ consumption with radiographic Knee OA was made by Qin et al. ${ }^{(11)}$ and Zeng $\boldsymbol{e t}$ al. (12). In whites, but not in African Americans, Qin et al. (11) found a moderate inverse threshold relationship between dietary magnesium consumption and knee OA. They explained this difference by the relatively small sample size of African American participants in this study, which was not enough to judge (30\%). In addition, the quality of diet was poor. Furthermore, Zeng et al. ${ }^{\left({ }^{12}\right)}$ found in his study that Mg consumption is negatively related to radiographic knee $\mathrm{OA}$ and joint space narrowing, supporting $\mathrm{Mg}$ 's potential involvement in the prevention of knee OA.

Shmagel et al. ${ }^{\left({ }^{13}\right)}$, on the other hand, found that reduced magnesium consumption was related with poorer pain and function in knee OA, particularly among those with low fiber intake. According to the most recent study in this area, Veronese et al. ${ }^{(14)}$ verified that a greater dietary consumption of $\mathrm{Mg}$ is related with an increase in mean cartilage thickness, cartilage volume at medial tibia, cartilage volume and mean cartilage thickness at central medial femur, and cartilage volume and mean cartilage thickness in the central medial tibiofemoral compartment in the MRI.

According to our study, the mean serum $\mathrm{Mg}$ level in the OA group was $1.97 \pm 0.17 \mathrm{mg} / \mathrm{dl}$ and the mean level of $\mathrm{Mg}$ in the control group is $2.09 \pm 0.15$ $\mathrm{mg} / \mathrm{dl}$ with high statistically significance decrease in patients with knee OA in comparison with the controls. This finding is consistent with results of Zeng $\boldsymbol{e t} \boldsymbol{a l}$. (15)'s study who found that serum $\mathrm{Mg}$ level was strongly correlated with radiographic knee $\mathrm{OA}$. Mg levels were also shown to be lower in female OA twins by Hunter et al. ${ }^{(16)}$.

According to our study, Patients with knee OA exhibited lower $\mathrm{Mg}$ levels than the controls. However, serum $\mathrm{Mg}$ levels were not associated with the inflammatory biomarkers (CRP and ESR). This is in agreement with the study of Benlidayı et al. ${ }^{(17)}$, who reported that $\mathrm{Mg}$ levels in the severe OA group were considerably lower than in the moderate OA group $(\mathrm{p}=0.044)$. However, in this patient group, this did not correlate with the inflammatory markers CRP and ESR. In contrast, Dibaba et al. ${ }^{(18)}$ and Konstari et al. (19) revealed that magnesium consumption is inversely related to CRP levels in the blood. However, Li et al. (20) demonstrated that both dietary and serum $\mathrm{Mg}$ were inversely associated with serum CRP in early radiographic knee OA patients. Therefore, our study suggests that there is no significant relationship between serum $\mathrm{Mg}$ level in knee OA patients and diabetic, dyslipidemic or hypertensive states.

Interestingly, in patients with radiographic knee OA, Wang et al. ${ }^{(9)}$ found that serum $\mathrm{Mg}$ concentration was adversely related to the prevalence of diabetes mellitus and dyslipidemia. Unlike the prevalence of hypertension, this negative association was not observed. On the other hand, in a meta-analysis research involving ten prospective cohort studies, Han et al. ${ }^{(21)}$ discovered that magnesium concentration was linked to a reduced risk of hypertension occurrence. According to his findings, higher dietary magnesium consumption was linked with a decreased incidence of hypertension in a linear dose-response pattern. However, no direct relation was identified between serum magnesium concentration and the risk of hypertension. Sontia and Touyz ${ }^{(22)}$ demonstrated that reduced magnesium concentrations are associated with endothelial dysfunction, increased vascular reactivity, increased vascular tone, and elevated blood pressure, whereas increased magnesium levels are associated with opposite effects.

Dyslipidemia and diabetes have been identified as risk factors for the progression of knee $\mathrm{OA}^{(\mathbf{2 3}, \mathbf{2 4})}$. Similarly, serum $\mathrm{Mg}$ levels have been found to be substantially related with CRP ${ }^{\mathbf{( 8 , 2 5 )}}$, and elevated CRP may be used as a predictive factor for development of knee $\mathrm{OA}^{(26)}$. OA development can therefore be slowed by increasing serum $\mathrm{Mg}$ level by reducing $\mathrm{DM}$ prevalence and CRP levels. However, the specific mechanism requires further explanation. 
Regarding the correlation between serum $\mathrm{Mg}$ and the different scores included in the current study, there was non-significant weak positive correlation between serum $\mathrm{Mg}$ level and pain at rest score and pain at activity score. However, Shmagel et al. (13) demonstrated that, in knee OA, lower magnesium consumption was linked to worse pain and function in knee OA. This result may require a longitudinal research with a great sample. In our study, although serum $\mathrm{Mg}$ level in OA patients was significantly higher than in controls, there was no correlation between serum Mg level and the grade of OA using Kellgren score. In our mind, this may be due to the following: (1) the participants in our study were from rural areas. The majority were farmers and work hard all the time, which may worsen the knee condition. (2) On the other hand, the quality of food in rural areas, which focuses on the whole grains and non-mineralized water may increase the $\mathrm{Mg}$ level a little. For these reasons, further longitudinal (follow up) studies will be needed to compare this effect between rural and urban population.

\section{CONCLUSION}

Serum $\mathrm{Mg}$ concentration may have an inverse relationship with radiographic knee OA. Therefore, high level of $\mathrm{Mg}$ could possibly exert a protective role in the control of knee OA and can be used in its management.

\section{REFERENCES}

1. Lane N, Brandt K, Hawker G et al. (2011): OARSI-FDA initiative: defining the disease state of osteoarthritis. Osteoarthritis and Cartilage, 19 (5): 478-482.

2. Asch A, Bole B, Brandt B et al. (1986): Development of criteria for classification and reporting of osteoarthritis : classification of osteoarthritis of knee. Arthritis \& Rheumatism: Official Journal of the American College of Rheumatology, 29: 1039-1049.

3. Zeng C, Wang Y, Wei J et al. (2015): Association between low serum magnesium concentration and hyperuricemia. Magnesium Research, 28 (2): 56-63.

4. Zhang Y, Xu J, Qin $L$ et al. (2016): Magnesium and osteoarthritis: from a new perspective. Annals of Joint, 1(10): 113.

5. Reddy S, Soman S, Yee J (2018): Magnesium balance and measurement. Advances in Chronic Kidney Disease, 25 (3): 224229.

6. Alhosaini M, Leehey D (2015): Magnesium and dialysis: the neglected cation. American Journal of Kidney Diseases, 66 (3): 523-531.

7. Konttinen Y, Sillat T, Barreto G et al. (2012): Osteoarthritis as an autoinflammatory disease caused by chondrocyte-mediated inflammatory responses. Arthritis and Rheumatism, 64 (3): 613 616.

8. Kim D, Xun P, Liu K et al. (2010): Magnesium intake in relation to systemic inflammation, insulin resistance, and the incidence of diabetes. Diabetes care, 33 (12): 2604-2610.

9. Wang Y, Wei J, Zeng C et al. (2018): Association between serum magnesium concentration and metabolic syndrome, diabetes, hypertension and hyperuricaemia in knee osteoarthritis: a cross-sectional study in Hunan Province, China. BMJ Open, 8 (9): 19159-63.

10. Kellgren J, Lawrence J (1957): Radiological assessment of osteo-arthrosis. Annals of the Rheumatic Diseases, 16: 4-9.

11. Qin B, Shi X, Samai P et al. (2012): Association of dietary magnesium intake with radiographic knee osteoarthritis: Results from a population-based study. Arthritis Care \& Research, 64 (9): 1306-1311.

12. Zeng C, Wei J, Li H et al. (2015): Relationship between serum magnesium concentration and radiographic knee osteoarthritis. The Journal of Rheumatology, 42 (7): 1231-1236.

13. Shmagel A, Onizuka N, Langsetmo L et al. (2018): Low magnesium intake is associated with increased knee pain in subjects with radiographic knee osteoarthritis: data from the Osteoarthritis Initiative. Osteoarthritis and Cartilage, 26 (5): 651658.

14. Veronese N, La Tegola L, Caruso $M$ et al. (2019): The Association between Dietary Magnesium Intake and Magnetic Resonance Parameters for Knee Osteoarthritis. Nutrients, 11(6):1387-43.

15. Zeng C, Li H, Wei J et al. (2015): Association between Dietary Magnesium Intake and Radiographic Knee Osteoarthritis. PLoS One, 10 (5): 127-133.

16. Hunter D, Hart D, Snieder H et al. (2003): Evidence of altered bone turnover, vitamin $\mathrm{D}$ and calcium regulation with knee osteoarthritis in female twins. Rheumatology, 42 (11): 13111316.

17. Benlidayı İ, Gökçen N, Sarpel T (2017): Serum magnesium level is not associated with inflammation in patients with knee osteoarthritis. Turkish Journal of Physical Medicine and Rehabilitation, 63 (3): 249-253.

18. Dibaba D, Xun P, He K (2014): Dietary magnesium intake is inversely associated with serum C-reactive protein levels: metaanalysis and systematic review. European Journal of Clinical Nutrition, 68 (4): 510-516.

19. Konstari S, Sares-Jäske L, Heliövaara M et al. (2019): Dietary magnesium intake, serum high sensitivity $\mathrm{C}$-reactive protein and the risk of incident knee osteoarthritis leading to hospitalization-A cohort study of 4,953 Finns. Plos One, 14 (3): 214-218.

20. Li H, Zeng C, Wei J et al. (2017): Associations of dietary and serum magnesium with serum high-sensitivity $\mathrm{C}$-reactive protein in early radiographic knee osteoarthritis patients. Modern Rheumatology, 27 (4): 669-674.

21. Han H, Fang X, Wei X et al. (2017): Dose-response relationship between dietary magnesium intake, serum magnesium concentration and risk of hypertension: a systematic review and meta-analysis of prospective cohort studies. Nutrition Journal, 16 (1): 1-12.

22. Sontia B, Touyz R (2007): Role of magnesium in hypertension. Archives of Biochemistry and Biophysics, 458 (1): 33-39.

23. Schett G, Kleyer A, Perricone C et al. (2013): Diabetes is an independent predictor for severe osteoarthritis: results from a longitudinal cohort study. Diabetes Care, 36 (2): 403-409.

24. Eymard F, Parsons C, Edwards M et al. (2015): Diabetes is a risk factor for knee osteoarthritis progression. Osteoarthritis and Cartilage, 23 (6): 851-859.

25. Chacko S, Song Y, Nathan L et al. (2010): Relations of dietary magnesium intake to biomarkers of inflammation and endothelial dysfunction in an ethnically diverse cohort of postmenopausal women. Diabetes Care, 33 (2): 304-310.

26. Smith J, Martins T, Gopez E et al. (2012): Significance of Creactive protein in osteoarthritis and total knee arthroplasty outcomes. Therapeutic Advances in Musculoskeletal Disease, 4 (5): 315-325. 